\title{
Women's Empowerment and Its Determinants in Bangladesh: Evidence from a National Survey
}

\author{
Kanchan Kumar Sen* and Shahnaz Nilima \\ Department of Statistics, Dhaka University, Dhaka-1000, Bangladesh
}

(Received: 10 April 2018; Accepted: 12 June 2018)

\begin{abstract}
The potential factors associated with women's empowerment in household decision making as well as attitudes toward wife beating were determined in the study. The Bangladesh Demographic Health Survey (BDHS), 2014 data were used to get the determinants of women's empowerment. To measure the women's empowerment, the principal component analysis was used in the study. The ordinal logistic regression model was applied to determine the potential factors for women's empowerment. Results were also compared with the results obtained from classical linear regression model. The study revealed that lower difference of spousal ages and lower number of daughters were more likely to increase women's empowerment. Similar to other studies, early marriage and living in rural area gave the women lower empowerment but education, 1-4 family members, having at least one child, exposed to media, belonging to NGO and working outside home had greater positive influence on women's empowerment.
\end{abstract}

Keywords: Empowerment, Principal component analysis, Ordinal response, Proportional odds model.

\section{Introduction}

Women's empowerment is considered as an important topic of interest throughout the world. Socio-economic development of a nation cannot be attained without equal participation of women ${ }^{1}$. Gender inequality is a violation of human rights and barrier to women's empowerment as well as prosperity of a country ${ }^{1}$. Achievement of gender equality, realization of women's equal rights and involvement of women in all decision making areas are prerequisites for sustainable development. As the role of women in attaining social, political and economic development is crucial, reducing gender disparities and empowering women are considered as central development objectives all over the world.

For advancement of women rights, the United Nations Beijing Platform for Action of 1995 committed to empower women in twelve critical areas. Twenty years after the adoption of the Platform for Action, progress remains insufficient to reduce gender discrimination and violence against women and enhance women's participation in all areas $^{2}$. The necessity of promoting gender equality and empowering women has been recognized in the United Nations Conference on Sustainable Development, held in 2012. The commitment to achieve gender equality and ensure women's equal and active participation in economic, social and political decision making processes for sustainable development has been also articulated in the outcome document of the UN conference ${ }^{3}$. While sufficient progress has been made in reducing gender gap and empowering women under third Millennium development goal (MDG), discrimination and violence against women still remain more prevalent in developing countries compared to developed countries. To accelerate the pace of success of MDG 3, sustainable development goal (SDG) 5 targets are the commitments to end gender disparity, violence against women and ensure women's equal rights and active participation of women at all levels of decision making by 2030 for faster and sustainable development across the world.

Bangladesh is one of the low human development index (HDI) countries in the south with high gender inequalities ${ }^{4}$. To measure gender disparity, Global Gender Gap index introduced by World Economic Forum is constructed considering four basic outcome variables (health, access to education, participation in economy and political empowerment) ${ }^{5}$. The 2014 Global Gender Gap report reveals that Bangladesh has achieved $68^{\text {th }}$ position out of 146 countries in terms of Global Gender Gap index which demonstrates increased prevalence of gender inequalities 5 . According to Bangladesh Demographic and Health Survey 2014 report, about $60 \%$ of Bangladeshi women experience physical or sexual violence ${ }^{6}$. To reduce such high prevalence of violence against women in Bangladesh, the importance of promoting female empowerment is obvious. Although female labor force participation has raised in Bangladesh in recent years, it needs more attention to achieve fifth sustainable goal targets ${ }^{7}$.

Various studies have investigated the factors associated to women's empowerment worldwide. Habibov et al. conducted a study in Azerbaijan and showed that women's educational attainment and level of earnings equal or higher than their partners is positively related with increased level of empowerment ${ }^{8}$. A study by Bushra and Wajiha reveals that women education, economic involvement and opportunities and poverty are the significant determinants of women in Pakistan ${ }^{9}$. Gupta and Yesudian conducted a study in India and found that women's educational level, media exposure and age are important predictors of women's empowerment using multiple logistic analysis ${ }^{10}$. Rahman et al. investigated that women's education and age have significant impact on women's empowerment among microcredit borrowers in Bangladesh ${ }^{11}$. To identify the important determinants of women's empowerment, Rahman et al. collected information from 500 ever married women of Chapai Nawabganj district in Bangladesh and performed

*Author for correspondesnce. e-mail: kksen.sta@du.ac.bd 
logistic regression analysis. Their study reveals that women's education, media exposure, age at marriage significantly influence women's decision making power ${ }^{12}$. Dey and Khudri showed that women's age, division, women's education, employment status, religion, wealth index and number of living children have significant influence on women empowerment ${ }^{13}$. The findings of two studies suggest that access to education, working status and exposure to media contributes significantly to promote women empowerment in Bangladesh ${ }^{14-15}$.

In this study, we attempt to explore the evidence of women's empowerment and identify its key determinants in Bangladesh.

\section{Data and Methodology}

\section{Data}

We have used BDHS, 2014 data for conducting secondary analysis on women's empowerment. The information of women was collected based on two-stage stratified sampling in BDHS, 2014. In the first stage, 600 enumeration areas (EA) were selected and then 30 households were selected from each EA by applying a systematic sampling in the second stage. The respondents or women of 17,863 aged 15-49 were interviewed in BDHS, $2014^{6}$. In the study, 16,350 women aged 15-49 were selected instead of 17,863 women because of some missing observations in the data.

\section{Outcome variable}

Women's empowerment in household is a latent variable because it cannot be measured directly. It was measured based on two other latent variables: women's participation in household decision-making and their attitudes toward wife beating ${ }^{6}$. Firstly, Women's participation in household decision-making was measured based on four indicators. The women were asked who took decisions about their own health care, making major household purchases, child's health care, and visits to the family or relatives. For the above questions, we made four binary variables (yes/no) where 'yes' was defined for the responses of 'respondent alone', 'respondent and husband/partner' or 'respondent and other person', and 'no' for otherwise. Secondly, women's attitudes toward wife beating was measured based on five indicators where women were asked about their opinion on whether a husband is justified in hitting if she refuses to have sex with him, goes out without his permission, neglects children, argues with him, or burns the food. The response "yes" of the above questions means that she believes wife-beating is justified and "no" means she rejects wife-beating for that particular reason. For our analysis purpose, the responses to these questions were recoded i.e. a value of 1 was assigned if "no" and 0 for "yes" and hence we got five indicators. Thirdly, we took all nine indicators (4 decisions and 5 reasons) to create women's empowerment. Principal component analysis (PCA) has been used to get index score of women's empowerment from all nine indicators. The women with higher score have more empowerment in the family than the women with lower score. We divided the index scores into three equal parts based on quantiles. We named the three equal parts as low, medium and high for below first quantile, between first and second quantile, and above second quantile, respectively. Finally, the score index with three categories is our desired outcome variable. So the outcome variable women's empowerment has three ordered categories: low, medium and high, where low meant women have lower empowerment and high meant women have higher empowerment.

\section{Study covariates}

After reviewing some studies related women's empowerment, we selected the covariates which were included in our study. The selected covariates were women's age at first marriage, education level, age difference of married couples, number of living children, current working status, wealth index, religion, husband's occupation, number of household members, difference of number of daughters and sons, media exposure, NGO membership, place of residence and division. Women's education gap was made by taking difference between the spousal education levels and categorized it into no difference, wife with higher education and wife with lower education. We took the difference of women's total daughters with their total sons to know the influence of daughters on their mother's empowerment and we categorized it into no difference, more sons and more daughters. The media exposure was categorized into "yes" if the respondent exposed to any of listening radio, watching television and reading newspaper and magazines and "no" if she was not exposed. Women's NGO membership was categorized into two categories: "yes" if she belongs to any of Grameen bank, BRAC, BRDB, ASHA, Proshika, mother's club and other NGOs and "no" if she does not belong to NGOs.

\section{Ordinal Logistic Regression Model}

Several regression models such as multinomial logistic, ordinal logistic regression models etc. are used for analyzing polychotomous data. For the ordinal response, it is necessary to use ordinal logistic regression model to get precise and efficient estimates of the regression coefficients. In most of the previous studies, the ordinal logistic regression models for ordinal data have been broadly used ${ }^{16-20}$. The proportional odds model (POM), partial proportional odds model (PPOM), continuous ratio model (CRM) etc, are all the ordinal logistic regression models. In practice the proportional odds model is often used for ordinal data.

In our study the response variable has been classified into three categories (low, medium and high) according to an order of magnitude. The proportional odds model has been used in the study. Let the response variable $Y$ (women's empowerment) with $k$ categories and the $\tilde{x}=\left(x_{1}, x_{2}, \ldots, x_{p}\right)$ 'vector of $p$ explanatory variables. Then the proportional odds model is written as 
$\lambda_{j}(\tilde{x})=\ln \left\{\frac{\sum_{1}^{j} P(Y=j \mid \tilde{x})}{\sum_{j+1}^{k} P(Y=j \mid \tilde{x})}\right\}=\alpha_{j}+\sum_{i=1}^{p} \beta_{i} x_{i}, i=$

$1,2, \ldots, p ; j=1,2, \ldots, k-1$,

where $\alpha_{j}$ is the $j^{\text {th }}$ intercept and $\beta_{i}$ is the $i^{\text {th }}$ regression coefficient $^{21}$. We have used proportional odds model for both adjusted and unadjusted odds ratios.

For the purpose of comparison of the results obtained from ordinal logistic regression model, we have also used classical linear regression model in the study. STATA 14 package has been used in the study for analyzing the data.

\section{Results and Discussion}

The ever-married women of 16,350 aged 15-49 were selected from BDHS, 2014 to study their empowerments in household. Most of the selected women $(76.02 \%)$ in the study married early (before age of 18 years). The mean difference of spousal age was almost 9 years which meant that the husbands are almost 9 years older than their wives. The study selected $66 \%$ women from rural area and the rest from urban area. Among the women, only 31\% worked outside the home and $34 \%$ women involved in NGO as members. In recent, Bangladeshi women's involvement in reading newspaper, listening radio or watching television have been increased than before. Now, the $63 \%$ women of Bangladesh exposed in media. Women's education has been also increased i.e. only $22 \%$ women are non-educated. Among the women, 54\% women had one or two living child and $37 \%$ women had more than two living child.

Table 1 represents the associations of women's background characteristics with their empowerment in household. To measure the associations, the unadjusted odds ratios were determined by using the proportional odds model.

Table 1. Association between different background characteristics of women with their empowerment obtained from unadjusted proportional odds model (POM).

\begin{tabular}{|c|c|c|c|}
\hline $\begin{array}{c}\text { Background } \\
\text { characteristics }\end{array}$ & OR & $\begin{array}{c}\text { Background } \\
\text { characteristics }\end{array}$ & OR \\
\hline $\begin{array}{l}\text { Age at first } \\
\text { marriage }\end{array}$ & & Religion & \\
\hline Age $<18$ & 1.00 & Muslim & $0.79 * * *$ \\
\hline Age $\geq 18$ & $1.27 * * *$ & Non-Muslim & 1.00 \\
\hline $\begin{array}{l}\text { Spousal age } \\
\text { difference }\end{array}$ & $0.99 * * *$ & $\begin{array}{l}\text { Working } \\
\text { status }\end{array}$ & \\
\hline $\begin{array}{l}\text { Education } \\
\text { level }\end{array}$ & & No & 1.00 \\
\hline $\begin{array}{l}\text { No education } \\
\text { Primary }\end{array}$ & $\begin{array}{l}1.00 \\
0.99\end{array}$ & $\begin{array}{l}\text { Yes } \\
\text { Husband's } \\
\text { occupation }\end{array}$ & $1.26 * * *$ \\
\hline Secondary & $1.13 * * *$ & Farmer & 1.00 \\
\hline Higher & $1.88 * * *$ & Labour & 1.03 \\
\hline $\begin{array}{l}\text { Number of } \\
\text { living children }\end{array}$ & & Business & $1.20 * * *$ \\
\hline No child & 1.00 & Service & $1.42 * * *$ \\
\hline $1-2$ & $2.48 * * *$ & Others & 0.89 \\
\hline $3-4$ & $2.63 * * *$ & Place & \\
\hline
\end{tabular}

\begin{tabular}{|c|c|c|c|}
\hline \multirow{4}{*}{$\begin{array}{l}4+ \\
\text { Difference of } \\
\text { daughter and }\end{array}$} & \multicolumn{3}{|c|}{ residence } \\
\hline & $1.98 * * *$ & Urban & 1.00 \\
\hline & & & $0.69 * * *$ \\
\hline & $0.89 * * *$ & Rural & \\
\hline No difference & 1.00 & Division & \\
\hline More Sons & 1.08 & Barisal & $0.53 * * *$ \\
\hline More daughters & $0.85 * * *$ & Chittagong & $0.74 * * *$ \\
\hline $\begin{array}{l}\text { Number } \\
\text { household }\end{array}$ & & Dhaka & \\
\hline members & & & 1.00 \\
\hline $1-4$ & 1.00 & Khulna & $0.63 * * *$ \\
\hline $5-7$ & $0.79 * * *$ & Rajshahi & $0.66 * * *$ \\
\hline $7+$ & $0.56 * * *$ & Rangpur & $0.78 * * *$ \\
\hline Media & & & \\
\hline exposure & & Sylhet & $0.53 * * *$ \\
\hline No & 1.00 & Wealth index & \\
\hline Yes & $1.50 * * *$ & Poorest & $0.78 * * *$ \\
\hline NGO & & Poorer & $0.89 * *$ \\
\hline Membership & & & \\
\hline No & 1.00 & Middle & 1.00 \\
\hline Yes & $1.12 * * *$ & Richer & $1.12 * *$ \\
\hline & & Richest & $1.75 * * *$ \\
\hline
\end{tabular}

It is observed that all the covariates presented in Table 1 were found significant associations $(p<0.05)$ with women's empowerment in household. Thus, it is said that early marriage, spousal age difference, no education, no living child, more daughters, large family size, unexposed in media, unemployed, living in rural area and living with poor family decrease women's empowerment. Again, women of several divisions compared to Dhaka and wives of farmers compared to other wives have lower empowerment.

Table 2. Adjusted odds ratios of women's empowerment for different covariates obtained from proportional odds model.

\begin{tabular}{|c|c|c|c|}
\hline $\begin{array}{l}\text { Background } \\
\text { characteristics }\end{array}$ & OR & $\begin{array}{l}\text { Background } \\
\text { characteristics }\end{array}$ & $\mathbf{O R}$ \\
\hline $\begin{array}{l}\text { Age at first } \\
\text { marriage }\end{array}$ & & Religion & \\
\hline Age $<18$ & 1.00 & Muslim & $0.78 * * *$ \\
\hline Age $\geq 18$ & $1.14 * * *$ & Non-Muslim & 1.00 \\
\hline $\begin{array}{l}\text { Spousal age } \\
\text { difference }\end{array}$ & $0.99 * *$ & $\begin{array}{l}\text { Working } \\
\text { status }\end{array}$ & \\
\hline $\begin{array}{l}\text { Education } \\
\text { level }\end{array}$ & & No & 1.00 \\
\hline No education & 1.00 & Yes & $1.18 * * *$ \\
\hline Primary & 1.03 & $\begin{array}{l}\text { Husband's } \\
\text { occupation }\end{array}$ & \\
\hline Secondary & $1.20 * * *$ & Farmer & 1.00 \\
\hline Higher & $1.75 * * *$ & Labour & 1.03 \\
\hline $\begin{array}{l}\text { Number of } \\
\text { living }\end{array}$ & & Business & \\
\hline children & & & 0.95 \\
\hline No child & 1.00 & Service & 1.09 \\
\hline $1-2$ & $2.65 * * *$ & Others & 0.90 \\
\hline
\end{tabular}




\begin{tabular}{|c|c|c|c|}
\hline $3-4$ & $3.66^{* * *}$ & $\begin{array}{ll}\text { Place } & \text { of } \\
\text { residence } & \end{array}$ & \\
\hline $4+$ & $3.60 * * *$ & Urban & 1.00 \\
\hline $\begin{array}{l}\text { Difference of } \\
\text { daughter and } \\
\text { son }\end{array}$ & & Rural & $0.91 * *$ \\
\hline No difference & 1.00 & Division & \\
\hline $\begin{array}{l}\text { More Sons } \\
\text { More }\end{array}$ & 1.01 & $\begin{array}{l}\text { Barisal } \\
\text { Chittagong }\end{array}$ & $0.61 * * *$ \\
\hline daughters & $0.86 * * *$ & & $0.81 * * *$ \\
\hline Family size & & Dhaka & 1.00 \\
\hline $1-4$ & 1.00 & Khulna & $0.66^{* * *}$ \\
\hline $5-7$ & $0.74 * * *$ & Rajshahi & $0.69^{* * *}$ \\
\hline $7+$ & $0.55^{* * *}$ & Rangpur & $0.90^{* *}$ \\
\hline $\begin{array}{l}\text { Media } \\
\text { exposure }\end{array}$ & & Sylhet & $0.67 * * *$ \\
\hline No & 1.00 & Wealth index & \\
\hline Yes & $1.10^{* *}$ & Poorest & $0.80^{* * *}$ \\
\hline $\begin{array}{l}\text { NGO } \\
\text { membership }\end{array}$ & & Poorer & 0.92 \\
\hline No & 1.00 & Middle & 1.00 \\
\hline Yes & $1.09 * *$ & Richer & $\begin{array}{l}1.05 \\
1.45^{* * * *}\end{array}$ \\
\hline \multicolumn{4}{|l|}{ Intercepts } \\
\hline$\widehat{\alpha_{1}}$ & 0.81 & & \\
\hline$\widehat{\alpha_{2}}$ & 3.78 & & \\
\hline
\end{tabular}

Table 2 presents the adjusted odds ratios for women's empowerment obtained from the proportional odds model. All the covariates except husband's occupation used in multivariate analysis were found to be significant on women's empowerment. The early married women (age below 18 years) are less likely to have empowerment than those who married at age of 18 years or above. Spousal age difference has negative relation with women's empowerment. With increase of spousal age difference, women's empowerment decreases in the household. Compared to women who have no education, the odds of having empowerment were $20 \%$ and $70 \%$ higher for women who completed secondary and higher education, respectively but there was no significant difference exist between non educated and primary educated women. Thus it can be said that more education gives the women more empowerment in their family. Mothers who have 1-2, 3-4 and $4+$ children are $2.65,3.66$ and 3.60 times likely to have empowerment compared to women with no children, respectively. Compared to mothers who had equal number sons and daughters, the odds of getting empowerment was $14 \%$ lower for those women who had more daughters but the odds for women who had more sons did not show significant difference. Thus, it is revealed that with the increase of daughters, mother's empowerment decrease in the family. Women with 5-7 and 7+ family members are less likely to establish empowerment than those women with 7+ family members, respectively. It is said that larger family size does not improve women's empowerment. Women who were not exposed in media have $10 \%$ higher odds of having empowerment compared to those women who were exposed in media. Compared to women who are NGO members, the odds of having empowerment were $10 \%$ higher for women who are not involved in NGO. It was observed that Muslim women have lower empowerment in the family compared to non-Muslim women. Working women are more likely to establish empowerment in the family. From Table 1 is observed that there did not exist significance difference of women whose husbands were labours, businessmen, servicemen or others with those women whose husbands were farmers. Women who are live in rural area are less likely to have empowerment than those women who are live in urban area. It is found that women from Barisal, Chittagong, Khulna, Rajshahi and Sylhet divisions have lower empowerment in decision making as well as attitudes toward wife beating compared to women from Dhaka. The poorest women have $20 \%$ lower odds of having empowerment but the richest women have $45 \%$ higher odds of having empowerment in household decision making as well as attitudes toward wife beating compared to middle class women.

Table 3. Adjusted regression coefficients of different covariates obtained from linear regression model.

\begin{tabular}{|c|c|c|c|}
\hline $\begin{array}{l}\text { Background } \\
\text { characteristics }\end{array}$ & $\begin{array}{c}\text { Estimate } \\
(\beta)\end{array}$ & $\begin{array}{l}\text { Background } \\
\text { characterist } \\
\text { ics }\end{array}$ & $\begin{array}{c}\text { Estimate } \\
(\boldsymbol{\beta})\end{array}$ \\
\hline $\begin{array}{l}\text { Age at first } \\
\text { marriage }\end{array}$ & & Religion & \\
\hline Age $<18$ & Ref. & Non-Muslim & Ref. \\
\hline Age $\geq 18$ & $0.102 * * *$ & Muslim & $-0.224 * * *$ \\
\hline $\begin{array}{l}\text { Spousal age } \\
\text { difference }\end{array}$ & -0.003 & $\begin{array}{l}\text { Working } \\
\text { status }\end{array}$ & \\
\hline $\begin{array}{l}\text { Education } \\
\text { level }\end{array}$ & & No & Ref. \\
\hline No education & Ref. & Yes & $0.164 * * *$ \\
\hline Primary & 0.048 & $\begin{array}{l}\text { Husband's } \\
\text { occupation }\end{array}$ & \\
\hline Secondary & $0.215 * * *$ & Farmer & Ref. \\
\hline Higher & $0.530 * * *$ & Labour & 0.036 \\
\hline $\begin{array}{l}\text { Number of } \\
\text { living }\end{array}$ & & Business & \\
\hline children & & & 0.029 \\
\hline No child & Ref. & Service & $0.153 * * *$ \\
\hline $1-2$ & $0.662 * * *$ & $\begin{array}{l}\text { Others } \\
\text { Place of }\end{array}$ & -0.103 \\
\hline $3-4$ & $0.932 * * *$ & residence & \\
\hline $4+$ & $0.922 * * *$ & Urban & Ref. \\
\hline $\begin{array}{l}\text { Difference of } \\
\text { daughter and } \\
\text { son }\end{array}$ & & & -0.057 \\
\hline No difference & Ref. & Division & \\
\hline $\begin{array}{l}\text { More Sons } \\
\text { More }\end{array}$ & 0.016 & $\begin{array}{l}\text { Barisal } \\
\text { Chittagong }\end{array}$ & $-0.460 * * *$ \\
\hline daughters & $-0.190 * * *$ & & $-0.183 * * *$ \\
\hline Family size & & Dhaka & Ref. \\
\hline $1-4$ & Ref. & Khulna & $-0.290 * * *$ \\
\hline $5-7$ & $-0.245^{* * *}$ & Rajshahi & $-0.238 * * *$ \\
\hline $7+$ & $-0.446 * * *$ & Rangpur & -0.055 \\
\hline
\end{tabular}




\begin{tabular}{|c|c|c|c|}
\hline $\begin{array}{l}\text { Media } \\
\text { exposure }\end{array}$ & & Sylhet & $-0.319 * * *$ \\
\hline No & Ref. & $\begin{array}{l}\text { Wealth } \\
\text { index }\end{array}$ & \\
\hline Yes & $0.128 * * *$ & Poorest & $-0.217 * * *$ \\
\hline $\begin{array}{l}\text { NGO } \\
\text { membership }\end{array}$ & & Poorer & $-0.084 * *$ \\
\hline No & Ref. & Middle & Ref. \\
\hline Yes & $0.090 * * *$ & Richer & 0.026 \\
\hline & & Richest & $0.312 * * *$ \\
\hline
\end{tabular}

Significance: $* * * \mathrm{p}<0.01, * * \mathrm{p}<0.05$

In this paper, linear regression model has also been fitted to find the determinants of women's empowerment considering score obtained from principal component analysis of nine indicators as continuous variable. The results presented in Table 3 shows the estimated regression coefficients of the covariates for women's empowerment obtained from linear regression model. It is shown that all the covariates except spousal age difference and place of residence have significant effects on women's empowerment. The results in Table 3 are approximately similar to that of Table 2. Since both models give approximately same results in the study, it is revealed that either linear regression model or proportional odds model can be used for index score response variable.

\section{Conclusions}

Empowerment is essential for women to develop the family as well as the society. In the study, we tried to find out some potential factors that have influence on women's empowerment in household decision making and also attitudes toward wife beating based on BDHS, 2014 data. The ordinal logistic regression model i.e. proportional odds model has been applied for analyzing women's empowerment. All the covariates included in the study were significantly associated with women's empowerment in bivariate analysis, although husband's education did not show significant association in multivariate analysis. From the results of adjusted odds ratios, it can be summarized that early marriage, spousal age difference, no education, no living child, more daughters, large family size, unexposed in media, no working, living in rural area and living with poor family do not improve women's empowerment in the family. These women in the family are facing problem most to participate in household decision making as well as attitudes toward wife beating. To improve empowerment among these particular women, some proper steps such as increasing literacy and media facility for rural women, improving family planning services, preventing early marriage etc. should be taken so that they can get opportunity to contribute to the family as well as society.

There were some limitations in the study. Firstly, women's empowerment was measured by taking only women's attitudes toward wife beating and household decisionmaking variables but women's freedom of movement, economic freedom etc., were not included to define women's empowerment. Secondly, only women's current patterns of attitudes toward wife beating and decisionmaking were used to define empowerment but ignored past patterns, while some studies revealed that current patterns of empowerment reflect past patterns ${ }^{22}$. Thirdly, only women were asked about their decision-making and attitudes toward wife beating patterns but did not ask their husbands.

\section{Acknowledgement}

We are thankful to the National Institute of Population Research and Training (NIPORT) of the Ministry of Health and Family Welfare, Bangladesh for allowing us to use the BDHS, 2014 data. We are also thankful to Professor Dr. Wasimul Bari, University of Dhaka for his valuable comments at different stages of this study.

\section{References}

1. Bayeh, E. 2016. The role of empowering women and achieving gender inequality to the sustainable development of Ethiopia. Pacific Science Review B: Humanities and Social Sciences 2, 37-42.

2. United Nations Entity for Gender Equality and the Empowerment of Women. 2015. The Beijing Platform for Action: Inspiration then and now. (Retrieved from http://beijing20.unwomen.org/en/about).

3. United Nations (U.N.). 2014. World Survey on the Role of Women in Development. Gender Equality and Sustainable Development. United Nations, New York.

4. United Nations Development Program (UNDP), 2013. Human Development Report 2013. New York, NY: UNDP.

5. World Economic Forum. 2014. The Global Gender Gap Report 2014. Geneva: Switzerland.

6. Bangladesh Demographic and Health Survey (BDHS), 2014. National Institute of Population Research and Training (NIPORT) of the Ministry of Health and Family Welfare. ICF International of Rockville, Maryland, USA and Dhaka, NIPORT, Mitra and Associates.

7. Bangladesh Bureau of Statistics (BBS). 2013. Gender Statistics of Bangladesh 2012. Dhaka: Planning Division, Ministry of Planning.

8. Habibov, N., B. J. Barrett and E. Chernyak. 2017. Understanding women's empowerment and it's determinants in post-communist countries: Results of Azerbaijan national survey. Women's Studies International Forum 62, 125-135.

9. Bushra, A. and N. Wajiha.2015.Assessing the socioeconomic determinants of women empowerment in Pakistan. Procedia-Social and Behavioral Sciences.177, 3-8.

10. Gupta, K. and P. P. Yesudian. 2006. Evidence of women's empowerment in India: a study of socio-spatial disparities. GeoJournal. 65(365-380).

11. Rahman, S., P. N. Junankar and J. Mallick. 2009. Factors influencing women' empowerment on microcredit borrowers: a case study in Bangladesh. Journal of Asia Pacific Economy. 14(3) : 287-303.

12. Rahman, M., U. K. Karmaker and A. R. Mia.2009. Determinants of women empowerment at domestic and non- 
domestic issues: evidence from Chapai Nawabganj District in Bangladesh. Dhaulagiri Journal of Sociology and Anthropology.3 (143-162).

13. Dey, R. and M. M. Khudri.2015.Assessment of key dimensions and determinants of women's empowerment in Bangladesh.Russian Journal of Agricultural and SocioEconomic Sciences.37,38-47.

14. Khatun, M. 2009. The Empowerment of Women: They are Coming Anyway. The Bangladesh Journal of Political Economy. 24: 663-680.

15. Ahmed, S. and M. Khatun. 2008. Gender Relations in Postmodern Societies: Impact of Globalization on Women's Position. Journal of Knowledge Globalization 1, 109-125.

16. McCullagh, P. 1980. Regression models for ordinal data. J R Stat Soc B, 42(109-142).

17. Anderson, J. A. 1984. Regression and ordered categorical variables. J R Stat Soc B, 46(1-30).
18. Brant, R. 1990. Assessing proportionality in the proportional odds model for ordinal logistic regression. Biometrics, 46(1171-80).

19. Lee, J. 1992. Cumulative logit modeling for ordinal response variables: Application in biochemical research. Compt Appl Biosci, 8(555-562).

20. Ananth, C. V. and D. G. Kleinbaum. 1997. Regression models for ordinal responses: A review of methods and applications. Int J Epidemiol, 26(1323-33).

21. Das, S. and M. R. Rajwanur. 2011. Application of ordinal logistic regression analysis in determining risk factors of child malnutrition in Bangladesh. Nutrition Journal. BioMed Central. 10: 124.

22. Hindin, J. M., 2000. Women's autonomy, women's status and fertility-related behavior in Zimbabwe. Population Research and Policy Review. 19(3), 255-282. 